\title{
CrimRxiv
}

\section{Violences en contexte conjugal et stratégies de protection adoptées par les femmes}

Guisela Patard, Frédéric Ouellet

Published on: Mar 03, 2022

DOI: $10.21428 / \mathrm{cb} 6 a b 371 . a 9 e a 8 f 28$

License: Creative Commons Attribution 4.0 International License (CC-BY 4.0). 
